\begin{tabular}{|c|c|c|c|}
\hline$\Omega$ & D & $\equiv$ & (2) \\
\hline $\begin{array}{l}\text { Beatrix Langara', } \\
\text { Svetlana Georgieva², } \\
\text { Waseem A. Khan', } \\
\text { Praveen Bhatia3', } \\
\text { Muntasir Abdelaziz³ }\end{array}$ & $\begin{array}{l}\text { 'Dept of Respiratory Medicine, } \\
\text { Tameside General Hospital, } \\
\text { Ashton Under Lyne, UK } \\
{ }^{2} \text { Dept of Medicine, Tameside } \\
\text { General Hospital, Ashton Under } \\
\text { Lyne, UK } \\
{ }^{3} \text { Respiratory and General } \\
\text { Medicine, Tameside General } \\
\text { Hospital, Ashton Under } \\
\text { Lyne, UK }\end{array}$ & $\begin{array}{l}\text { Praveen Bhatia, } \\
\text { Respiratory and General } \\
\text { Medicine, Tameside } \\
\text { General Hospital, Ashton } \\
\text { Under Lyne, OL6 9RW, UK. }\end{array}$ & Praveen.Bhatia@tgh.nhs.uk \\
\hline
\end{tabular}

\title{
Sudden cardiac death in a young man
}

\section{Case Report}

\section{Case presentation}

A 35-year-old man presented to the accident and emergency department with history of productive cough, breathlessness and some weight loss over several weeks. He had a past medical history of asthma and eczema. He mentioned that, at times, he had been expectorating sputum with some haemoptysis over the past few months. He was of Bangladeshi origin, but had been resident in the UK since 1986 and last visited Bangladesh a year ago. He was a smoker of 10-15 cigarettes per day. $\mathrm{He}$ also admitted to smoking heroin. In addition to his respiratory symptoms he also complained of vomiting, which was precipitated by eating. He denied bowel or urinary symptoms.

He was married, lived with his wife and three young children, denied any alcohol use and had no previous contact with tuberculosis (TB) patients.

\section{Investigations}

On clinical examination the patient was unwell. His temperature was $35.8^{\circ} \mathrm{C}$. His blood pressure was $98 / 62 \mathrm{mmHg}$, heart rate 110 beats $\cdot \mathrm{min}^{-1}$, respiratory rate 16 breaths $\cdot \mathrm{min}^{-1}$. He had bilateral pedal oedema with no clinical evidence of deep vein thrombosis. There were no palpable lymph nodes. Examination of the cardiovascular system was normal.

His blood tests showed a marginally raised white cell count (WCC) of $12.5 \times 10^{9}$ per $L$ and a hyponatraemia of $133 \mathrm{mmol} \cdot \mathrm{L}^{-1}$.

The patient had deranged liver function tests and a low glucose level of $2.1 \mathrm{mmol} \cdot \mathrm{L}^{-1}$ on admission, which was corrected with intravenous dextrose.

\section{Task 1}

What would be your initial investigations for a patient like this?

\section{Conflict of interest}

None declared. 


\section{Answer 1}

Bloods (full blood count, urea and electrolytes, and C-reactive protein), chest radiography, ECG, echocardiogram, and sputum for acid-fast bacilli

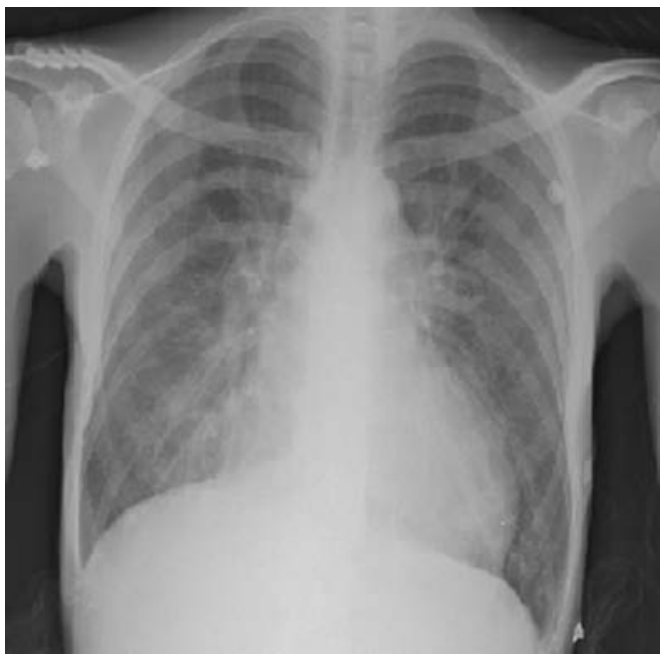

Figure 1

Chest radiograph.

\section{Task 2}

Can you name three abnormalities on the chest radiograph (fig. 1)?

\section{Answer 2}

Haziness is noted on the right, cardiac shadow is enlarged, and prominent bilateral hilar vasculature

His chest radiograph showed cardiomegaly and inflammatory changes in the right middle lobe. He was started on antibiotics (amoxicillin). The plan was to exclude TB by sending sputum for tests; blood samples were also sent for hepatitis and autoimmune screening.

An ultrasound scan of his abdomen showed that the gall bladder was thick walled and had sludge with pericholecystic fluid. The liver parenchyma appeared unremarkable. It was also noted that there was hepatic venous and inferior vena cava (IVC) congestion, and bilateral pleural effusions.

\section{Task 3}

What would be the initial diagnosis? 


\section{Answer 3}

$\mathrm{TB}$, respiratory tract infection, myocarditis

\section{Treatment}

The patient was initially stabilised in the department with correction of his low blood glucose by i.v. dextrose. He was also started on oral antibiotics to treat a chest infection.

\section{Task 4}

What could be a possible cause of low blood glucose in the patient?

\section{Answer 4}

Addisonian crisis

\section{Outcome and follow-up}

Unfortunately the patient became agitated and suffered a cardiac arrest. He underwent cardiorespiratory resuscitation for over $45 \mathrm{~min}$, but could not be resuscitated from his pulseless electrical activity arrest and unfortunately died. His post mortem showed that the lungs were markedly oedematous throughout. There was no bronchopneumonic consolidation. The pleura appeared healthy, but bilateral straw-coloured pleural effusions were present. The heart was enlarged weighing $450 \mathrm{~g}$. All the valves were unremarkable. Both ventricles appeared dilated. A thrombus was adherent to the wall of the left ventricle and the ventricle muscle underlying this area of thrombus appeared pale. Sections from this abnormal area of myocardium showed florid granulomatous inflammation with multinuclear giant cells. This was consistent with TB. The lungs showed pulmonary oedema and mild emphysema, but no histological evidence of TB.

\section{Task 5}

What are the hallmark histological findings of patients with TB? 


\section{Answer 5}

Caseating granulomas

\section{Discussion}

TB-related sudden death is mainly due to bronchopneumonia, massive haemoptysis and, rarely, cardiac complications of TB or adrenal gland involvement [1]. Only a few cases of sudden cardiac death due to TB myocarditis have been reported [2, 3], all of which have been diagnosed at autopsy. It has been postulated that the mechanism of death in these patient is due to a ventricular arrhythmia. HORN and SAPHIR [4] have described three histological types of myocardial TB. An interesting point to note is that it has been proposed that the myocardium can be affected either by direct extension, lymphatic drainage, or direct spread from tuberculous pericarditis [3]. It seems as though anatomically the right-sided mediastinal nodes make the myocardium most vulnerable to direct spread [5]. A point to note is that patients can remain clinically asymptomatic until quite late in the disease process.
The three histological types of myocardial TB are as follows:

1) Nodular tubercles (tuberculomas) of the myocardium, varying "from pea to egg size" with central caseation usually affecting the right side of the heart, particularly the right atrium.

2) Miliary tubercles of the myocardium complicating generalised miliary disease.

3) Uncommon diffuse infiltrative type, usually associated with tuberculous pericarditis, in which the myocardium is diffusely infiltrated by granulation tissue containing giant cells, endothelial cells and lymphocytes.

TB myocarditis is rarely diagnosed during life. It should be suspected in a patient with TB if patients present with a cardiac arrhythmia such as atrial fibrillation, paroxysmal ventricular tachycardia, ventricular fibrillation [6] or atrioventricular block [7]. Patients may continue to develop congestive heart failure [8], valve dysfunction or superior vena cava (SVC) obstruction [9]. Magnetic resonance imaging may be quite useful for detecting involvement of the myocardium $[10,11]$.

\section{Key points}

- TB-related sudden deaths are mainly due to bronchopneumonia, massive haemoptysis, Addisonian crisis, and arrhythmias secondary to myocarditis.

- TB myocarditis is an uncommon presentation in the acute setting.

- Myocarditis is a known complication and should be considered.

- These patients may present with cardiac arrhythmia which if not addressed may lead to cardiac arrest.

- TB treatment and high-dose steroids remain the mainstay of therapy.

\section{References}

1. Liu A, Hu Y, Coates A. Sudden cardiac death and tuberculosis - how much do we know? Tuberculosis (Edinb) 2012; 92: 307-313.

2. Biedrzycki OJ, Baithun SI. TB-related sudden death (TBRSD) due to myocarditis complicating miliary TB: a case report and review of the literature. Am J Forensic Med Pathol 2006; 27: 335-336.

3. Wallis PJW, Branfoot AC, Emerson PA. Sudden death due to myocardial tuberculosis. Thorax 1984; 39: 155

4. Horn $\mathrm{H}$, Saphir O. The involvement of the myocardium in tuberculosis: a review of the literature and report of three cases. Am Rev Tuberc 1935; 32: 492-506.

5. Maeder M, Ammann P, Rickli $\mathrm{H}$, et al. Fever and night sweats in a 22-year-old man with a mediastinal mass involving the heart. Chest 2003; 124: 2006-2009.
6. Behr G, Palin HC, Temperley JM. Myocardial tuberculosis. Br Med J 1977; 1: 951.

7. Kinare SG, Deshmukh MM. Complete atrioventricular block due to myocardial tuberculosis. Report of a case. Arch Pathol 1969; 88: 684-687.

8. Wilbur EL. Myocardial tuberculosis: a case of congestive cardiac failure. Am Rev Tuberc 1938; 38: 769-776.

9. Soyer R, Brunet A, Chevallier B, et al. Tuberculous aortic insufficiency. Report of a case with successful surgical treatment. J Thorac Cardiovasc Surg 1981; 82: 254-256.

10. Alkhulaifi AM, Carr CS. Right atrial tuberculoma: computed tomography and magnetic resonance imaging. J Thorac Cardiovasc Surg 2007; 133: 808.

11. Jagia P, Gulati GS, Sharma S, et al. MRI features of tuberculoma of the right atrial myocardium. Pediatr Radiol 2004; 34: 904-907. 